\title{
Academic achievement associated with motor performance and sex in different subcultures
}

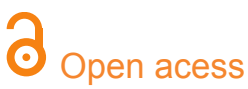

${ }^{1}$ Study Group on Motor Development and Health of child and adolescent Federal Institut of Ceará

2Study Group on Motor Evaluation and Intervention School of Physical Education / Federal University of Rio Grande do Sul

\section{Corresponding author:} salvianonobre@gmail.com

Manuscript received: 10 June 2017 Manuscript accepted: 02 July 2017 Version of record online: 06 September 2017

\author{
Francisco Salviano Sales Nobre1, Paulo Felipe Ribeiro \\ Bandeira $^{2}$, Nadia Cristina Valentini ${ }^{2}$
}

\begin{abstract}
Introduction: School and motor performances demonstrates achievements of children throughout childhood. Gender and the child's developmental context interfere with the differentiated trends of intensity and direction of school and motor performance.
\end{abstract}

Objective: To analyze the association among school performance, motor performance, and the sex of children of different subcultures

Method: The study included 233 children aged 7 to 10 years, 127 boys (8.2 \pm 0.92 years) and 106 girls (8.4 \pm 0.85 years), from three different subcultures (semi-arid, mountainous, and coastal weather) of Northeast Brazil. Data were collected from the School Performance Test and the Test of Gross Motor Development-2. Descriptive statistics, comparisons, and multivariate multiple linear regressions were used for analysis.

Results: It was found that school delays were prevalent in boys, and motor delays, specifically in object control skills, were prevalent in girls. Motor performance is positively associated with performance in writing, reading, and arithmetic, but this relationship is specific for each subculture.

Conclusion: There was an association among school performance, motor performance, and the sex of children in different Northeastern subcultures, evidencing the influence of subcultures and gender on the children's performance.

Keywords: environment, school performance, motor performance, child development 


\section{INTRODUCTION}

Associations between cognitive performance and motor performance have been the focus of recent research $^{1-3}$. It is known in neuroscience that motor and cognitive functions are performed by the same brain structures. For example, the cerebellum is involved in both motor and cognitive functions, and the prefrontal cortex plays an important role in these structures through neural connections ${ }^{4,5}$. Motor performance may act as a control parameter for the development of cognitive and perceptual abilities $^{6}$. Furthermore, children with cognitive deficits also present deficits in school performance variables such as arithmetic, reading, and writing ${ }^{7}$.

From an ecological perspective, it is known that personal characteristics - for example, the child's gender and development context - interfere in the differentiated

\section{METHODS}

\section{Participants}

The participant group consisted of children living in socially vulnerable communities in Northeastern Brazil. The population was composed of 272 children, and from a voluntary and non-probabilistic sample, 233 comprised the study sample. Parents and/or legal guardians signed the Free and Informed Consent Form (TCLE) of all participants. This work was approved by the Ethics Committee in Research with Human Beings (Process $n^{\circ}$ 19861)

\section{Assessment of School Performance}

The School Performance Test (SPT) developed by Stein $^{15}$ was used to evaluate the fundamental academic abilities, specifically, writing, arithmetic, and reading. The SPT is intended for the evaluation of students between 2 nd and 7 th grade of elementary school. The said instrument is composed of three subtests: a) writing (writing of the proper name and isolated words presented in the form of dictation); B) arithmetic (oral solution of problems and calculation of arithmetic operations in writing); and C) reading (recognition of words isolated from context). The gross score (GS) of each subtest and the total gross score (TGS) of the entire SPT are converted by means of a table in the classifications of upper, middle, and lower for each school series. That way, the information can be used to compare the performance of one individual to another.

\section{Motor Performance Evaluation}

Motor performance was evaluated by the Test of Gross Motor Development-2 (TGMD-2; Ulrich) ${ }^{16}$, which was authenticated for the Brazilian population ${ }^{17}$. The TGMD-2 is a process-oriented instrument that evaluates the performance characteristics of six HLOC locomotion

\section{RESULTS}

This study included 233 children, 127 boys ( 8.2 \pm 0.92 years) and 106 girls $(8.4 \pm 0.85$ years $)$, in the age group between 7 and 10 years old $(8.2+0.9$ years $)$, attending the $2 \mathrm{nd}, 3 \mathrm{rd}$, and 4 th years of the initial grades of elementary school I, from three different subcultures (58 semi-arid, 77 mountainous, and 98 coastal weather).

The average and standard deviations of the gross motor and school performance scores in all subtests in tendencies of intensity and directions of school and motor performance $^{8,9}$. Delays in school and motor performance are reported as more prevalent in socioeconomically impoverished populations ${ }^{9-12}$. Regarding gender, school performance impairment is more frequent among boys ${ }^{13}$, while delays in motor performance, especially in skills involving manipulation of elements (balls, rackets, clubs), are more prevalent among girls ${ }^{14}$.

Because of its important educational repercussions, this theme needs research in Brazil, working together with evidence of an association between school performance and motor performance ${ }^{1-3}$. Thus, the objective of this study is to analyses the association among school performance, motor performance, and the sex of children of different subcultures.

skills (running, galloping, one-legged jumping, passing jumping, horizontal jumping, and lateral running) and six HCO object controlling skills (bounce a ball, rebut, catch, kick, fling over, and fling under). Each skill is evaluated considering the presence or absence of three to five performance criteria ${ }^{16,17}$.

\section{Data Analysis}

Descriptive statistics of the frequency distribution type (absolute and relative values) were used to describe the school performance characteristics of boys and girls in each subculture. Average and standard deviation were used to describe the characteristics of school performance and locomotor skills and to control objects according to sex and context. Test ' $t$ ' for independent samples was used to compare school performance and motor skills performance of locomotion and object control between boys and girls according to context. Cohen's 'd' was used to estimate the size of the effect.

A multivariate multiple linear regression model was conducted through structural equation models to evaluate possible associations between dependent variables - performance in arithmetic, writing, and reading - and independent variables: gender ( 0 - female, 1- male) and motor skills (gross locomotion score and object control). The square distance of Mahalanobis $\left(\mathrm{D}^{2}\right)$ verified the existence of outliers, and the normality of the variables was evaluated by the coefficients of asymmetry (sk) and kurtosis (ku) uni and multivariate. Possible multicollinearities were investigated using VIF (variance inflation factor); FIV $>5$ were considered as indicators of multicollinearity ${ }^{18}$. We used AMOS $\AA$ ) software (see 22, SPSS, an IBM ${ }^{\circledR}$ Company, Chicago, IL, USA) and SPSS Statistics (see 21, SPSS, an IBM®Company).

each subculture of the Northeast are presented in Table 1. Differences between boys and girls were observed in school performance according to context. Regarding motor performance, exclusively in object control skills, only boys showed better performance when compared to girls in the mountain context $(\mathrm{t}=6.481, \mathrm{p}<0.001$, Cohen's $\mathrm{d}=1.50)$ and the coastal context $(\mathrm{t}=3.907 \mathrm{p}<0.001$, Cohen's d = 0.81) (Table 1). 
Table 1: Descriptive analysis of school and motor performance of girls and boys in different northeastern subcultures

\begin{tabular}{|c|c|c|c|c|c|c|c|c|c|c|c|c|}
\hline \multirow{3}{*}{ Performance } & \multicolumn{4}{|c|}{ Semi- arid } & \multicolumn{4}{|c|}{ Sawed } & \multicolumn{4}{|c|}{ Coastal } \\
\hline & \multicolumn{2}{|c|}{ Male } & \multicolumn{2}{|c|}{ Female } & \multicolumn{2}{|c|}{ Male } & \multicolumn{2}{|c|}{ Female } & \multicolumn{2}{|c|}{ Male } & \multicolumn{2}{|c|}{ Female } \\
\hline & $\mathrm{n}$ & M (SD) & $\mathrm{n}$ & $M(S D)$ & $\mathrm{n}$ & $M(S D)$ & $\mathrm{n}$ & $M(S D)$ & $\mathrm{n}$ & $M(S D)$ & $\mathrm{n}$ & M (SD) \\
\hline \multicolumn{13}{|l|}{ School } \\
\hline Writing & 32 & $5,8(6,8)$ & 26 & $9,5(3,7)$ & 39 & $12,3(5,1)$, & 38 & $11,8(10,1)$ & 56 & $9,4(8,1)$ & 42 & $11,9(9,6)$ \\
\hline Reading & 32 & $29,0(14,0)$ & 26 & $37,8(12,9)$ & 39 & $35,5(17,6)$ & 38 & $40,3(21,5)$ & 56 & $31,9(13,7)$ & 42 & $40,1(21,6)$ \\
\hline Arithmetic & 32 & $4,4(2,1)$ & 26 & $5,1(3,0)$ & 39 & $7,6(4,0)$ & 38 & $6,3(3,6)$ & 56 & $6,0(3,1)$ & 42 & $7,5(3,8)$ \\
\hline \multicolumn{13}{|l|}{ Motor } \\
\hline $\begin{array}{l}\text { Getting Around } \\
\text { Locomotion }\end{array}$ & 32 & $23,8(4,8)$ & 26 & $24,2(4,0)$ & 39 & $26,0(3,4)$ & 38 & $25,1(3,2)$ & 56 & $23,9(5,5)$ & 42 & $23,3(5,0)$ \\
\hline Object Control & 32 & $26,7(4,1)$ & 26 & $25,5(4,1)$ & 39 & $30,2(5,1)^{\mathrm{a}}$ & 38 & $23,0(4,6)^{\mathrm{a}}$ & 56 & $27,0(5,9)^{b}$ & 42 & $22,2(6,1)^{b}$ \\
\hline
\end{tabular}

a,bTest "t" for independent samples, p<0,005; M- Mean: SD- Standar deviation

The results of school performance indicate a lower achievement than expected for the range of education, regardless of gender and context. The performance in arithmetic was the most compromised, varying between $87.2 \%$ and $100 \%$ of performance categorized as inferior. The results regarding motor performance categorizations, based on a percentile lower than and/or equal to 5, showed that the great majority of the study participants were classified as inferior in performance (poor or very poor) when compared to the national norms established by the authors of the test ${ }^{15}$. Table 2 presents the school performance and motor performance categorizations for the three Northeastern subcultures in the subtests for both sexes (Table 2).

Table 2: Classification of school and motor performance of boys and girls in the different northeastern subcultures.

\begin{tabular}{|c|c|c|c|c|c|c|c|c|c|c|c|}
\hline \multirow{3}{*}{$\begin{array}{l}\text { Context \& } \\
\text { Classification } \\
\text { Performance }\end{array}$} & & \multicolumn{6}{|c|}{ School } & \multicolumn{4}{|c|}{ Motor } \\
\hline & & \multicolumn{2}{|c|}{ Writhing } & \multicolumn{2}{|c|}{ Reading } & \multicolumn{2}{|c|}{ Arithmetc } & \multicolumn{2}{|c|}{ Locomotion } & \multicolumn{2}{|c|}{ Object Control } \\
\hline & & Male & Female & Male & Female & Male & Female & Male & Female & Male & Female \\
\hline \multirow[t]{3}{*}{ Semi-arid } & Inferior & $26(81,3)$ & $22(84,6)$ & $26(81,3)$ & $23(88,5)$ & $32(100)$ & $24(92,3)$ & $31(96,9)$ & $25(96,2)$ & $30(93,8)$ & $22(84,6)$ \\
\hline & Midle & $6(18,8)$ & $4(15,4)$ & $6(18,8)$ & $3(11,5)$ & - & $2(7,7)$ & $1(3,1)$ & $1(3,8)$ & $2(6,2)$ & $4(15,4)$ \\
\hline & Superior & & - & - & - & - & - & - & - & - & - \\
\hline \multirow[t]{3}{*}{ Sawed } & Inferior & $24(61,5)$ & $21(55,3)$ & $23(59,0)$ & $23(60,5)$ & $34(87,2)$ & $35(92,1)$ & $38(97,4)$ & $38(100)$ & $33(84,6)$ & $35(92,1)$ \\
\hline & Midle & $11(28,2)$ & $14(36,8)$ & $13(33,3)$ & $13(34,2)$ & $3(7,7)$ & $2(5,3)$ & $1(2,6)$ & & $6(15,4)$ & $3(7,9)$ \\
\hline & Superior & $4(10,3)$ & $3(7,9)$ & $3(7,7)$ & $2(5,3)$ & $2(5,1)$ & $1(2,6)$ & - & - & - & - \\
\hline \multirow[t]{3}{*}{ Coastal } & Inferior & $33(58,9)$ & $29(69,0)$ & $34(69,7)$ & $30(71,4)$ & $53(94,6)$ & $39(92,9)$ & $52(92,9)$ & $41(97,6)$ & $49(87,5)$ & $36(85,7)$ \\
\hline & Midle & $22(39,3)$ & $10(23,8)$ & $20(35,7)$ & $9(21,4)$ & $3(5,4)$ & $3(7,1)$ & $4(7,1)$ & $1(2,4)$ & $7(12,5)$ & $6(14,3)$ \\
\hline & Superior & $1(1,8)$ & $3(7,1)$ & $2(3,6)$ & $3(7,1)$ & - & - & - & - & - & - \\
\hline
\end{tabular}

No variable presented FVD $<5$, indicating multicollinearity. In relation to the associations, the female sex was positively associated with writing performance in the semi-arid context. In the serrano and littoral contexts, the performance in reading stands out. In arithmetic, there was only association in the coastal context. These results indicate superiority in the performance of girls in these school skills in their respective contexts.

Regarding associations between motor performance and academic performance, locomotor skills were positively associated with writing in the semi-arid and coastal contexts, with reading in the semi-arid context and with arithmetic in the coastal context. Object control skills were also positively and significantly associated with writing in the mountain context, with reading in the semi-arid and serrano contexts. Table 3 presents the values of the standardized estimates, standard error, and $\mathrm{R}^{2}$ of the models (Table 3 ).

Table 3: Multivariate multiple regression between performance in arithmetic, writing and reading, gender, gross locomotion score and object control in different northeastern subcultures

\section{Connect}

\begin{tabular}{|c|c|c|c|c|c|c|c|c|c|c|}
\hline & & Semi-arid & & Sawed & & Coastal & & & & \\
\hline & & Estimate & Se & $\mathbf{R}^{2}$ & Estimate & Se & $\mathbf{R}^{2}$ & Estimate & Se & $\mathbf{R}^{2}$ \\
\hline writhing & & & & & & & & & & \\
\hline & Sex & $-3,77^{*}$ & 1,79 & 0,20 & $-3,36$ & 2,95 & 0,06 & $-3,46$ & 1,82 & 0,13 \\
\hline & Locomotion & $0,47^{*}$ & 0,21 & & $-0,10$ & 0,37 & & $0,46^{*}$ & 0,17 & \\
\hline & Object & 0,29 & 0,23 & & $0,54^{*}$ & 0,25 & & 0,144 & 0,15 & \\
\hline Reading & & & & & & & & & & \\
\hline & Sex & $-9,96$ & 5,33 & 0,31 & $-14,68^{*}$ & 7,15 & 0,8 & $-12,45^{\star}$ & 5,54 & 0,10 \\
\hline & Locomotion & $1,75^{*}$ & 0,63 & & 0,38 & 0,90 & & 0,91 & 0,51 & \\
\hline & Object Control & $1,74^{*}$ & 0,68 & & $1,33^{*}$ & 0,62 & & 0,59 & 0,46 & \\
\hline
\end{tabular}


Arithmetic

\begin{tabular}{lccccccccc} 
Sex & $-0,72$ & 0,92 & 0,07 & $-0,36$ & 1,33 & 0,09 & $-1,94^{*}$ & 0,87 & 0,12 \\
Locomotion & 0,15 & 0,11 & & 0,15 & 0,16 & & $0,19^{*}$ & 0,08 & \\
Object Control & 0,07 & 0,11 & & 0,21 & 0,11 & & 0,07 & 0,07 & \\
\hline
\end{tabular}

Note:Se- Standar Error; ${ }^{*} \mathrm{p}<0.05$

\section{DISCUSSION}

Children at social risk present school and motor delays, evidencing a lower school performance in reading, writing, and mathematics in the three subcultures of Northeastern Brazil (semi-arid, mountainous, and coastal weather). It was found that school delays were prevalent in boys, and motor delays, specifically in object control skills, were prevalent in girls. Motor performance was positively associated with performance in writing, reading, and arithmetic, but this relationship was specific for each subculture.

Regardless of the geographical region and culture of the children, residing in socially vulnerable communities is a risk factor for poor school performance. The results of this study confirm previous studies ${ }^{9,11}$ and reinforce the arguments that point to the socioeconomic level as the best predictor of school performance.

When it is found that children from the semi-arid context have the worse school performance, it is worth noting that despite the fact that the school census points to an improvement in the professional qualification of the semi-arid teachers in recent years, the regions classified as non-semi-arid still present a higher number of teachers with a higher level ${ }^{19}$. In addition, it is not uncommon to have cases in the semi-arid context in which the teachers' graduation is given through the short degree, where the understanding persists that students in the initial grades of basic education do not require better professional qualification of teachers ${ }^{20}$.

In general, the results suggest the need for ongoing training of teachers working in communities of social vulnerability and of specific compensatory strategies in school and motor performance to enable these children to reach higher levels of school performance that allow progress in subsequent grades without abandoning teaching for poor performance.

Regarding differences in school performance between the sexes, tests applied in educational assessments in the country have shown that boys perform better in mathematics and girls in reading ${ }^{11,21}$. This fact was only partially confirmed in this study, as a better performance of girls was observed in all subtests of school performance.

On the subject, Capellini et al. ${ }^{13}$, comment that greater difficulties to learn factual knowledge are more present in males. However, neuroscience recognizes that the brains of boys and girls are more alike than different, and such similarity is more common in adolescence with the event of puberty and brain plasticity that occurs according to the experiences in contexts ${ }^{22}$. In fact, in the present study it was observed that boys seemed to be encouraged earlier to help their parents in their professional activities (in the field in the mountain context and in artisanal fishing in the village of fishermen). In general, the families expected more dedication from the girls in school activities. This fact may partly explain the results found.

The low level of motor proficiency of children identified in this study may be as worrying as the level observed in school performance. It should be noted, however, that the phenomenon of motor delays occurs in different countries, including children of high socioeconomic level ${ }^{23}$, as well as those attended by nonsports social projects ${ }^{10}$. Yet it is known that this phenomenon of motor delays is more prevalent in schoolchildren living in situations of social vulnerability ${ }^{24}$, as observed in the present study.

Regarding the influences of sex on motor performance, as can be seen in Table 2, the results of this research corroborate with the literature that indicates similar performance in locomotion skills ${ }^{10,14}$, but with a predominance of better performance in motor skills, particularly the control of objects, in males ${ }^{10,14,23,24}$. In general, these motor delays can be explained by the weakness and disintegration of primordial environments to promote human development, first at home and then at school. In this way, the creation of other contexts and promoters of development would be necessary to overcome the coexisting deficiencies in the primordial environments ${ }^{25}$.

The results presented in Table 3, when evidencing associations between the locomotor and control abilities of objects with performance in writing, reading, and arithmetic, confirm the hypothesis of the present study, suggesting that the associations are specific to each context. For example, coastal schoolchildren presented a greater influence of locomotor skills on writing and arithmetic performance, whereas for mountainous students, motor proficiency in object control skills influences writing and reading performance. On the other hand, in the semi-arid context, the proficiency in locomotion and control of the object influences the performance in writing and, mainly, reading.

A previous study by Westendorp et al. ${ }^{1}$, in Australia showed a similar trend as observed in the present study. The authors report that Australian children showed significant correlations between performance in locomotor skills with writing and reading as well as significant correlations between performance in mathematics and object control skills. According to the authors, for Australian children, reading performance is importantly associated with locomotor performance, although there has been a tendency for math to be a predictor for performance in object control skills.

It is recommended to prioritize the development of control skills of objects with requisition, since we may require a rapid adaptation, stimulating more strongly the activation of the prefrontal cortex and cerebellum, which are also required in cognitive activities ${ }^{1}$. The results of the present study extend this recommendation and show that the importance of developing locomotor skill proficiency cannot be minimized.

It is a fact that there is an educational crisis in Brazil involving students, teachers, family, school, and the educational system as a whole 9 . The results of this study show that, specifically in socioeconomically disadvantaged contexts, this reality is detrimental to school performance 
and even more harmful to the development of motor skills, considering that for the population's belief system ${ }^{26}$, such abilities are rarely interpreted as essential to life. Although low, school performance still remains important for these families, while little importance is given to motor proficiency.

All efforts should be made to minimize the impact that social-risk environments have on children's development. Such actions require the adoption of public policies that aim to extend the permanence of children in educational environments that offer programmes that extrapolate their mere function of social assistance and that contribute to the physical, cognitive, affective, and motor development of learners.

The Brazilian educational policies of the last 20 years, in response to the demands of the social policies formulated by international agencies for the reduction of poverty, have given rise to a public school that confuses its role of teaching with a role of social reception ${ }^{27}$. As a result, in the short term learning fails to promote cognitive and motor learning, and in the long term eliminates the possibility of full development of learners.

All efforts should be made to minimize the impact that social-risk environments have on the development of children. Such actions require the adoption of public policies that aim to extend the permanence of children in educational environments that offer programmes that extrapolate their mere function of social assistance and that contribute to the physical, cognitive, affective, and motor development of learners.

\section{CONCLUSION}

There was an association among school performance, motor performance, and the sex of children in different Northeastern subcultures, evidencing the influence of subcultures and gender on the performance of these children. There was more compromised academic performance among boys, whereas motor performance in activities of object control was impaired among girls in situations of social risk.

\section{REFERENCES}

1. Westendorp M, Hartman E, Houwen S, Smith J, Visscher C. The relationship between gross motorskills and academic achievement in children with learning disabilities. Res Dev Disabil. 2011;32(6):2773-9. DOI: http://dx.doi.org/10.1016/j.ridd.2011.05.032

2. Lopes L, Santos R, Pereira B, Lopes VP. Associations between Gross motor coordination and academic achievement in elementary school children. Hum Mov Sci. 2013;32(1):9-20. DOI: http://dx.doi.org/10.1016/j.humov.2012.05.005

3. Saraiva JP, Rodrigues LP. Desenvolvimento motor e sucesso acadêmico. Que relação em crianças e jovens? Rev Port Educação. 2011;24(1):193-211. DOI: https://dx.doi.org/10.21814/rpe.3045

4. Diamond A. Close interrelation of motor development and cognitive development and of the cerebellum and prefrontal cortex. Child Dev. 2000;71(1):44-56. DOI: https://dx.doi.org/10.1111/1467-8624.00117

5. Stoodley CJ. The cerebellum and cognition: evidence from functional imaging studies. Cerebellum. 2012;11(2):352-65. DOI: https://dx.doi.org/10.1007/s12311-011-0260-7

6. Bushnell EW, Boudreau JP. Motor development and the mind: The potential role of motor abilities as a determinant of aspects of perceptual development. Child Dev. 1993;64(4):1005-21. DOI: https://dx.doi.org/10.1111/j.1467-8624.1993.tb04184.x

7. Alloway TP, Archibald L. Working memory and learning in children with developmental coordination disorder and specific language impairment. J Learn Disabil. 2008;41(3):251-62. DOI: https://dx.doi.org/10.1177/0022219408315815

8. Nobre FSS, Coutinho MTC, Valentini NC. The ecology of motor development in coastal schoolchildren of Brazil northeast. J Hum Growth Dev. 2014;24(3):263-73. DOI: https://dx.doi.org/10.7322/jhdg.88910

9. Padilha F, Érnica M, Batista AAG, Pudenzi L. As regularidades e exceções no desempenho do Ideb dos municípios. Estudos Aval Educ. 2012;23(51):58-81. DOI: http://dx.doi.org/10.18222/eae235120121948

10. Goodway JD, Robinson LE, Crowe H. Gender differences in fundamental motor skill development in disadvantaged preschoolers from two geographical regions. Res Q Exerc Sport. 2010; 81(1):7-24. DOI: http://dx.doi.org/10.1080/02701367.2010.10599624

11. Alves MTG, Soares JF. Contexto escolar e indicadores educacionais: condições desiguais para a efetivação de uma política de avaliação educacional. Educ Pesqui. 2013;39(1):177-94. DOI: http://dx.doi.org/10.1590/S1517-97022013000100012

12. Silva SCP, Gabbard C, Ries LG, Bobbio TG. Interlimb coordination and academic performance in elementary school children. Pediatr Int. 2016;58(10):967-73. DOI: http://dx.doi.org/10.1111/ped.12972

13. Capellini AS, Tonelotto JMF, Ciasca SM. Medidas de desempenho escolar: avaliação formal e opinião de professores. Estud Psicol. 2004;21(2):79-90. DOI: http://dx.doi.org/10.1590/S0103-166X2004000200006

14. Spessato BC, Gabbard C, Valentini N, Rudisill M. Gender differences in Brazilian children's fundamental movement skill performance. Early Child Dev Care. 2013;183(7):916-23.

DOI: http://dx.doi.org/10.1080/03004430.2012.689761

15. Stein LM. TED: teste de desempenho escolar: manual para aplicação e interpretação. São Paulo: Casa 
do Psicólogo; 1994; p.1-32.

16. Ulrich, DA. TGMD 2 - Test of gross motor development examiner's manual. 2 ed. Austin: Proed; 2000; p.4-60.

17. Valentini NC. Validity and reliability of the TGMD -2 for Brazilian children. J Mot Behav. 2012;44(4):27580. DOI: http://dx.doi.org/10.1080/00222895.2012.700967

18. Maroco J. Análise de equações estruturais: fundamentos teóricos, software \& aplicações. $2^{\mathrm{a}}$ ed. Pêro Pinheiro: ReportNumber; 2014; p.111.

19. Ribeiro ECM, Rodrigues LO, Silva MMC. Condições educacionais no Semiárido Brasileiro. [cited 2013 Apr 12]. Available from: http://www.ipece.ce.gov.br/publicacoes/textos_discussao/TD_85.pdf

20. Nascimento JÁ, Marques LR. Por uma qualidade da educação do semiárido. [cited 2017 Aug 18]. Available from: https://periodicos.ufpel.edu.br/ojs2/index.php/pensamentoplural/article/.../4260

21. Dias TL; Enumo SRF, Turini FA. Avaliação do desempenho acadêmico de alunos do ensino fundamental em Vitória, Espírito Santo. Estud Psicol. 2006;23(4): 381-90. DOI: http://dx.doi.org/10.1590/S0103-166X2006000400006

22. Eliot L. Cérebro azul ou rosa: o impacto das diferenças de gênero na educação. Porto Alegre: Penso; 2013; p.14.

23. Brauner LM, Valentini NC. Análise do desempenho motor de crianças participantes de um programa de atividades físicas. Rev Educ Física UEM. 2009;20 (2):205-16. http://dx.doi.org/10.4025/reveducfis.v20i2.6070

24. Costa CLA, Nobre GC, Nobre FSS, Valentini NC. Efeito de um programa de intervenção motora sobre o desenvolvimento motor de crianças em situação de risco social na Região do Cariri-CE. Rev Educ Fís UEM. 2014;25(3):353-64. DOI: http://dx.doi.org/10.4025/reveducfis.v25i3.21968

25. Bronfenbrenner U. A ecologia do desenvolvimento humano: experimentos naturais e planejados. Porto Alegre: Artes Médica; 1996; p.161-81.

26. Molina Neto V. Crenças do professorado de educação física das escolas públicas de Porto Alegre - RS, Brasil. Movimento. 2003;9(1):145-69.

27. Libâneo JC. O dualismo perverso da escola pública brasileira: escola do conhecimento para os ricos, escola do acolhimento social para os pobres. Educ Pesqui. 2012;38(1):13-28. DOI: http://dx.doi.org/10.1590/S1517-97022011005000001

\section{Resumo}

Introdução: O desempenho escolar e motor retratam conquistas de crianças ao longo da infância. O sexo e o contexto de desenvolvimento da criança interferem nas tendências diferenciadas de intensidade e direções do desempenho escolar e motor.

Objetivo: Analisar a associação entre o desempenho escolar, o desempenho motor e sexo de crianças de diferentes subculturas.

Método: Participaram da pesquisa 233 crianças oriundas de três diferentes subculturas (semiárido, serrana e litorânea) do Nordeste do Brasil. Os dados foram coletados a partir do Teste de Desempenho Escolar e o Test of Gross Motor Development-2. Para analise utilizaram-se da estatística descritiva, comparações e regressão linear múltipla multivariada.

Resultados: Verificou-se que atrasos escolares foram prevalentes nos meninos e os atrasos motores, especificamente em habilidades de controle de objetos, nas meninas. O desempenho motor associou-se positivamente com o desempenho na escrita, leitura e aritmética, sendo, porém, essa relação específica para cada subcultura.

Conclusão: Houve associação entre desempenho escolar, motor e o sexo de crianças nas diferentes subculturas nordestinas, evidenciando a influencia das subculturas e do sexo no desempenho dessas crianças.

Palavras-chave: ambiente, desempenho escolar, desempenho motor, desenvolvimento infantil

${ }^{\odot}$ The authors (2017), this article is distributed under the terms of the Creative Commons Attribution 4.0 International License (http://creativecommons.org/licenses/by/4.0/), which permits unrestricted use, distribution, and reproduction in any medium, provided you give appropriate credit to the original author(s) and the source, provide a link to the Creative Commons license, and indicate if changes were made. The Creative Commons Public Domain Dedication waiver (http://creativecommons.org/publicdomain/ zero/1.0/) applies to the data made available in this article, unless otherwise stated. 